Article

\title{
The City as an Agent of Refugee Integration
}

\author{
Jeroen Doomernik * and Djoeke Ardon \\ Amsterdam Institute for Social Science Research, University of Amsterdam, 1001NB Amsterdam; The Netherlands; \\ E-Mails: j.m.j.doomernik@uva.nl (J.D.), djoekeardon@gmail.com (D.A.) \\ * Corresponding author
}

Submitted: 27 June 2018 | Accepted: 7 September | Published: 20 December 2018

\begin{abstract}
In this contribution, we investigate how the role of cities in the governance of refugee integration has changed as a consequence of the Europeanization of asylum policies into a Common European Asylum System (CEAS) in conjunction with the "refugee crisis" of 2015, which this CEAS turned out to be unable to adequately cope with. We will answer this question by first giving a quick overview of scholarly thinking on the role of the city in global issues in general, and in migration issues in particular. After this we provide an exploratory analysis of the role cities presently see for themselves as cities, as well as jointly organized in European networks.
\end{abstract}

\section{Keywords}

asylum; city networks; Common European Asylum System; integration; migration; refugees

\section{Issue}

This article is part of the issue "European Cities Planning for Asylum", edited by Frank Eckardt (Bauhaus-Universität Weimar, Germany).

(C) 2018 by the authors; licensee Cogitatio (Lisbon, Portugal). This article is licensed under a Creative Commons Attribution 4.0 International License (CC BY).

\section{Introduction}

There is an important stream of literature arguing for a more local approach to global issues in general and, though less so, migration issues in particular. Authors such as Benjamin Barber and Saskia Sassen who famously coined the concept of the "global city", have noticed the political power and agency of cities in today's globalized world. Normally, states assume responsibility for those issues, yet cities may be better equipped to deal with them. Barber (2013) argues that we need a "global parliament of mayors" and implies that the centre of global governing should be within the city. Even though Barber's argument is slightly provocative, his reasons and arguments provide a new theoretical paradigm to look at the role of the local level within multi-level governance. In the field of migration studies, a "local turn" has taken place (Caponio \& Borkert, 2010; Zapata-Barrero, Caponio, \& Scholten, 2017). Where previously migration, refugee and asylum policies were by and large understood to be national in nature (e.g., Doomernik \& Jandl, 2008), more recently, and especially after the 2015 "asylum crisis", research increasingly includes the lower levels of governance, such as the special issue of the Journal of Refugee Studies on local refugee policies (Glorius \& Doomernik, 2016). A growing academic appreciation of the importance of multi-level governance, notably in the European Union (EU), has come together with the highly visible realities of the said "crisis" which have largely played out at the local level (Doomernik \& Glorius, 2016).

The present contribution focuses on cities and their networks as increasingly important players in the EU and its member states' response to the arrival of asylum seekers and refugees. When national sovereignty is at stake, as is the case with the admission of refugees and immigrants, individual cities - which we define as urban administrative units, and usually the lowest rung of national political stratification-as a rule execute policies decided upon at the national level. However, we can observe how cities contest policies or seek and exercise discretion when national policies turn out to be unenforceable, politically undesirable or at cross-purposes 
with their specific mandate (e.g., maintaining public order; see, for the Dutch case, Kos, Maussen, \& Doomernik, 2016; for the US, Canada and the UK see Bauder, 2017). Cities steering their own course is thus not particularly new or unique for Europe. However, it would seem that two developments together have boosted their role: the growing Europeanization of asylum policies, thus opening up new opportunities for political venue-shopping for city governments above the national level; and the unexpectedly high influx of asylum seekers in 2015, which put considerable strain on the EU's ability to jointly deal with their arrival. In effect, cities all over Europe had to act in the face of national governments that were overburdened or even unwilling to take responsibility (Doomernik \& Glorius, 2016). The present article asks how this has changed the role European cities identify for themselves and how they organize horizontally and vertically in response to these new challenges.

Next, we provide an overview of the main arguments arising out of the scholarly literature as to why cities claim (and some would say deserve) agency in the governance of immigration and refugee integration. Then we proceed to sketch what the main European city networks lobby for. For this we review their policy documents. In other words: we limit ourselves to statements issued by local governments, singly and collectively. Obviously, this does not result in a representative image of what cities' positions are, for those who do not participate in networks that clearly promote a larger role for themselves and (usually meaning) inclusive policies remain out of view. Finally, we evaluate in which domains these present policy ambitions depart from those that traditionally belong to the realm of urban governance, and thus those that represent a European "local turn" in response to the "refugee crisis".

\section{Cities and Governance}

A first reason why cities are becoming more important in global governance lies in growing populations and ditto economic impact. Just over half of the world's population lives in cities and these earn $60 \%$ of global GDP. Refugees too predominantly resettle in cities.

Also in terms of political legitimacy, cities have features distinguishing themselves from national or supranational governments. Mayors often boast approval rates 2 or 3 times higher than those of national legislators or chief executives (Barber, 2013, p. 84). Cities are more intimate to their population than national governments. For the European Commission, this is one of the motives for engaging local governments with its policies (De Mulder, 2017).

A third argument why cities matter for global politics is the fact that they are politically better suited for it than nation states. Or at least, as Barber (2013, p. 74) provocatively writes: "Nation states have not shown much capacity to rule the world". According to Barber (2013, p. 4), in the face of increasing globalisation, cities must be the agents of change. He identifies two advantages of cities over states. First, while nation states' efforts at cooperation can be "crippled by the issue of sovereignty", cities do not face such limits. They are thus less likely to become venues of nationalistic politics. Secondly:

The seeming indifference of cities to power politics and sovereignty, a feature that distinguishes them from states, is critical to their inclination to out-reach and networking. They prefer problem solving to ideology and party platforms, which is a core strength critical to their network potential. That they lack appetite for sovereignty and jurisdictional exclusivity enables them as agents of cross border collaboration. (Barber, 2013, p. 71)

Similarly, Kratz and Nowak (2017) demonstrate how the city embodies reason and pragmatism against a rising populist tide in the EU and the US alike.

In today's globalized world, cities are increasingly networked; they are collaborating internationally in a wide variety of inter-city networks in which they are quite effective. We will see below that there are many city networks doing productive work in lobbying, policy transfer and policy initiation in Europe's migration policy field. Cities such as Stuttgart, Barcelona, Hamburg, Vienna and Amsterdam have become hubs of urban networking, spawning new associations almost every year.

Cities appear to possess the unique combination of representing a level of governance that is local and thus able to represent pragmatism, efficiency and legitimacy, but at the same time being able to learn from each other through horizontal networking, e.g., about how to navigate vertical relationships, and formulating cooperative solutions with other cities in the world.

\section{Cities and Migration}

Most immigrants arrive in cities, where they work and go to school, find houses, do groceries and look for healthcare. Refugees, which we treat as a sub-category of migrants, are in particular need of support from local governments in terms of education, language and healthcare. Therefore, immigration is a prime example of a global issue playing out at the local level, both in the field of integration and in the field of citizenship. Furthermore, cities deal practically with immigrants, even though national governments exercise their role as the sovereign who decides about admission and membership for those who are non-nationals. Indeed, as the Organization for Economic Development and Cooperation (OECD) observes, the cost of integrating refugees is largely borne by sub-central governments, which is funded through lump sum payments from the national level, where the various and varying needs of refugees in local contexts is not taken into account (OECD, 2017).

Next to inclusion and integration policies, national membership status itself is also defined and acted out 
within cities, especially when this is about more than legal status. As Isin (2000, p. 6) notes: "Global cities are spaces where the very meaning, content and extent of citizenship are being made and transformed".

Varsanyi (2006), Daamen and Doomernik (2014) and many others describe how citizenship is transformed within the city. For instance, in many cities in the US, immigrants without a status are given school board voting rights and can pay in-state tuition fees of universities (instead of the tuition fees for non-nationals). Furthermore, the cities either issue the immigrants with driving licences, or accept certain proofs of identity (such as the Mexican Matriculas consulares) or locally issued ID cards in lieu of driving licences or official passports (Bauder, 2017). While in European countries, notably the welfare states among them, national control regimes tend to be stricter, these do not prevent the irregular residence of immigrant and failed asylum seekers. This can result in the de facto acceptance of their presence by city governments. In other words, citizenship can exist in practice without it being granted by law. The main reasons for cities to offer this alternative to legally based citizenship can be simple pragmatism in view of insufficient enforcement capacities, local economic interests, or priorities within community policing, which are mandates that are particular to their level of governance (as compared to national mandates that need to consider wider sets of interests; Spencer, 2018). In addition, ambiguities in national policies, resulting in policy gaps (Hollifield, Martin, \& Orrenius, 2014), can force or tempt city governments to close these gaps at the local level.

Bauböck (2003) similarly argues that in cities, membership is not given on the basis of abstract notions of giving consent to enter a bounded community, but instead upon the mere reality of presence and residence in a place. Next to the classical distinction between nationality by descent (jus sanguinis) and by birthplace (jus soli), this form of citizenship could be called jus domicili, i.e., rights based on residence. Consequentially one could argue for "constitutional politics that would strengthen local self-government by redefining boundaries, membership and rights at the level of municipal polities". (Bauböck, 2003, p. 139).

What is more, theorists and scholars such as Bauböck (2003) and Barber (2013), De Graauw and Vermeulen (2016) see a clear role for cities in the field of migration. Cities "fix and manage" most practical issues such as integration, housing, work and education for immigrants, but they also play a role in shaping and negotiating citizenship itself. Local policies are more likely to provide immigrants with equal opportunities and have an eye for the importance of ethnic diversity and immigrant political participation (Garcés-Mascarenas \& Chauvin, 2016). To be sure: we should not only be optimistic and simplistic about cities as agent of integration. Cities can act in exclusionary ways too if electoral realities force them to. For example, some cities in Spain refuse to register irregular immigrants and thereby counteract their legal access to healthcare, and some municipalities in Italy exclude irregular migrants from public housing. Additionally, in some localities, anti-immigrant parties and attitudes are growing, which is jeopardizing the inclusion of immigrants at the local level (Garcés-Mascarenas \& Chauvin, 2016).

\section{What Role Do Cities See for Themselves When It Comes to Managing Refugee Migration in the EU?}

It is not only scholars arguing for a larger role for the local level within the migration field. Cities themselves, and especially their transnational networks, are vocal in arguing for a more important role. In most if not all policy documents, statements and initiatives, cities and city networks emphasize and ask recognition for their importance in the migration field. Migrants come to cities, and cities have to take care for migrants, and do so when no other institution is able to (Council of European Municipalities and Regions [CEMR], 2015).

As agents in immigrant policymaking, cities often claim they are neglected by national governments. In the remainder of this paper, we ask what role cities see for themselves in this respect. We look at policy statements, position papers, letters, initiatives, and the actions of cities. In order to analyse the role cities see for themselves, we have selected a wide array of city networks (see Table 1). We do not claim to have an exhaustive list of networks and initiatives. We only surveyed those city networks that address migration policy on their websites. We started with Barber's (2013) list of city networks and initiatives and added networks if they were mentioned in one of the documents we analysed. We have analysed all of their published material with the research question in mind. It is important to note that in these documents, there is a natural emphasis on change; on areas where cities demand more influence than they presently have. What is reported partly reflects the current role cities play and is focused on the future role they see for themselves.

There are different dimensions to the field of migration. Do cities want to play a role within all those dimensions? And what are those dimensions exactly?

Alexander (2003, pp. 48-50) offers a useful classification of policy domains and issue areas within the migration field. He identifies four local policy domains. Firstly, there is the legal-political domain, which addresses the civic incorporation of migrants/ethnic minorities in the host polity. This is the dimension where issues of allocation and citizenship play a role. Secondly, there is the socio-economic domain, which concerns social inclusion policies. Thirdly, Alexander defines the cultural-religious domain, which includes policies related to minority, religious and cultural practices as well as to inter-group cultural relations. Finally, Alexander points to the spatial domain, which groups policies with a strong spatial dimension (housing, urban renovation, symbolic spaces). Below we offer an inventory of what role cities envisage for those four policy domains. As shall become 
Table 1. List of reviewed city networks.

UIA (Urban Innovative Actions) is an initiative of the EU and promotes and subsidizes sustainable urban development. Issues include environment, employment, migration and employment (Urban Innovative Actions, n.d.).

Urban Agenda for the EU, hosted by the European Commission, was initiated by the city government of Amsterdam in 2016 and covers a wide range of urban topics, including the integration of refugees (Urban Agenda for the EU, n.d.).

EUROCITIES has close to 200 members and partners. Collaboration is on a wide range of issues and includes refugee integration (EUROCITIES, n.d.).

The CEMR represents sixty national associations of regional and local governments, who together have 130,000 members, and extends beyond the EU (CEMR, n.d.).

United Cities and Local Governments (UCLG) is a global network of which CEMR is the European regional section (UCLG, n.d.).

VNG International is the international branch of the Association of Netherlands Municipalities (VNG International, n.d.).

clear, cities have distinct logics in formulating their policy goals and in identifying their target populations (cf., Jørgensen, 2012).

\section{Legal Political Domain: Negotiating Citizenship, Negotiating Policy}

City networks voice complaints about the Dublin III regulation, which stipulates as a core principle of the Common European Asylum System (CEAS) that the European country an asylum seeker (someone who asks to be recognized as a refugee) first sets foot on, is and remains responsible for all that follows, be it integration, temporary protection, or rejection and deportation. This results in uneven burdens for member states and for their cities, notably at the EU's outer borders. Arguably it was this principle that turned the arrival of Syrian and other refugees in the summer of 2015 into a crisis of the EU's professed goal of political solidarity (Den Heijer, Rijpma, \& Spijkerboer, 2016). It also means that a recognized refugee is not at liberty to move to a location in the EU where chances for integration (for instance by finding employment) are highest. Cities therefore argue for a revised allocation model, out of solidarity with communities in border regions and with refugees trying to enter the $\mathrm{EU}$ :

The Dublin III regulation should be revised. This regulation puts pressure on the external border regions of the EU, where the majority of asylum seekers enter the EU and where local authorities are often the least able to offer a large number of asylum seekers adequate support and protection. (EUROCITIES, 2015a, p. 3)

Cities voice their (political) ideas on citizenship, especially the fact that refugees should benefit from free movement within the EU. EUROCITIES, in the same statement from 2015, argues for:

The establishment of a principle of mutual recognition of refugee or international protection status and the possibility of transfer of protection status across
Europe for recognised refugees. They should benefit from the right of free movement and establishment in Europe as soon as they are granted refugee status. (EUROCITIES, 2015a, p. 3)

Similarly, but with the imposition of a single restriction, CEMR (2015) asserts that "refugees who find a job in another country, should have the opportunity to move to that member state".

Furthermore, cities demand more involvement in designing and implementing a new directive for the allocation of refugees as part of the CEAS:

Cities should be involved in the implementation of this directive to allow them to prepare for the reception of and provision of services to asylum seekers. (EUROCITIES, 2015a, p. 3)

Without the involvement of local and regional governments there can be no practical implementation of the agreements concluded at EU and national levels. (CEMR, 2015)

Cities moreover identify a distinct role for themselves in adequately dealing with rejected asylum seekers, an issue that is generally understood to be difficult to solve from a national level:

City authorities, if they wish to do so, should be more extensively supported by European institutions, member states and international organisations to enable them to offer quality information to those rejected and those dropping out of the asylum procedure, as well as to provide mediation and guidance regarding the voluntary return option. (EUROCITIES, 2015a, p. 2)

Besides negotiating EU asylum policy, cities may play an active role in shaping citizenship. As Garcés-Mascarenas \& Chauvin (2016 p. 52) note:

The incorporation of irregular immigrants takes mostly place at the local level: it is precisely 
there...where the practices of street-level bureaucrats, the support of non-governmental organisations and the development and implementation of particular local policies counteract the exclusionary effects of immigration policies.

To facilitate this process, city governments for instance may fund local NGOs working in the field of social and legal assistance. Barcelona offers a very interesting example when it turned the municipal census into the basis of what was defined as 'resident citizenship'. In effect, everyone registered in the city is considered a legitimate citizen, and has rights to healthcare, education, and municipal services such as libraries, sports centres and some social benefits.

But in many cities, citizenship takes shape through daily practice. For example, the Platform for International Cooperation on Undocumented Migrants (PICUM) has written a report together with EUROCITIES on how cities mitigate the impact of restrictive national policies regarding access to healthcare services. Where national governments limit access to public health systems, by requiring residence status in order to receive care, cities use their authorities to legislate or otherwise act in the field of health policy or delivery of care. As funders, cities support initiatives that facilitate improved access to services for their undocumented residents, for instance by providing it for free or anonymously. Examples from the report illustrate how cities have used a variety of strategies to improve access:

Including funding local clinics in Helsinki and Warsaw; partnering with local NGOs to provide integrated, community-based care in Frankfurt; easing administrative burdens in Ghent; campaigning to raise awareness of the right to health services in Madrid; and funding coverage for services denied under national plans in Eindhoven, Amsterdam, Nijmegen and Utrecht. (Smith \& Levoy, 2017, p. 31)

By doing this, undocumented immigrants are included in the city as residents, and cities are reshaping the-oftenexclusionary-national citizenship policies (for the Dutch case see also Kos et al., 2016).

But cities can go and do go further. As mentioned above, Barcelona includes all immigrants in the municipal population register, regardless of their migration status within their city, providing them not only with healthcare rights, but also making it possible for them to access education, public institutions such as the library, and even certain forms of benefits (Garcés-Mascarenas $\&$ Chauvin, 2016).

To conclude, cities have their own political ideas on allocation, settlement, deportation and membership rules for immigrants. City networks argue for freedom of movement for refugees within the EU, hereby countering the current Dublin regulation. Following their logic, cities also demand more involvement in decision making on allocation of refugees at the EU and national level. Finally, the local level has significant impact on how citizenship works in practice. Cities mitigate national restrictive policies, and include migrants into the city as residents, thereby reshaping the actual meaning of citizenship.

\section{The Spatial and Socio-Economic Domains: Autonomy, Policy Transfer and the Request for More Support}

\subsection{Labour Market}

Often, cities are responsible for the labour market integration of refugees. In the Netherlands, for instance, we see how cities have different types of labour market integration programmes (Razenberg \& De Gruijter, 2017). Dutch cities develop numerous initiatives and seek autonomy for making labour market integration policies. First, through assessments and intake conversations, municipalities try to assess "their" refugees' skills and strengths. Furthermore, municipalities like Amsterdam and Utrecht have "case managers" and "job coaches" for each refugee. Municipalities actively work together with local companies and employers and actively mediate between companies and refugees, also for internships and voluntary work arrangements. They organize visits to local companies with refugees, or "meet and greets" for employers and refugees. What becomes visible too is that localities often find it easier to integrate refugees with specific skills into their own labour markets. As a result of earlier more or less random distribution mechanisms in which all Dutch municipalities had to accommodate a centrally determined fixed share of refugees, mismatches between labour market needs and the refugees' human capital easily occurred. To counter this problem, the high-tech city of Eindhoven has developed a labour market integration policy specifically aimed at technically skilled English-speaking refugees. In other places, such as greenhouse regions, demand is mostly for lowskilled agricultural workers, whereas these municipalities have problems integrating highly educated refugees (Razenberg \& De Gruijter, 2017). Allocation of refugees could be improved to make the host society a better match overall with the incoming human capital. Finally, private and civil society initiatives are also very relevant in labour market integration, and cities often cooperate with those. In Finland, for instance, cities support various initiatives, which help to connect refugees to available jobs (EUROCITIES, 2016).

\subsection{Housing}

The city networks we reviewed mention that housing immigrants is among their largest challenges. Often, housing is scarce and pricy. Also in terms of public policy legitimacy and the general public's awareness, housing plays a large role. Cities work with their own housing stock, use mediators to reach out to private landlords, refur- 
bish empty office buildings, and coordinate solidarity initiatives among residents willing to host refugees in their homes (EUROCITIES, 2016). Yet national rules and regulations make it hard to fundamentally change the situation. As the cities assembled in the Urban Agenda for the EU remark:

The exceptions for situations of 'humanitarian urgency' should become more accepted as a common practice. For example, exceptions should be made in the EU sphere of competition and internal market for certain forms of housing for refugees. (Emergency) accommodation such as tiny houses, modular housing, containers, laneway housing etc. should be subject to more lenient rules on state aid and public procurement. (Urban Agenda for the EU, 2017, p. 39)

Meanwhile, cities have the possibility to combine housing with their goal of social inclusion: civil society and housing corporations can be included in the policymaking. For instance, in Antwerp, young unaccompanied refugees who come of age and are no longer eligible for welfare benefits can participate in a housing scheme where they are matched with young local citizens (buddies) and given training and job opportunities (Urban Innovative Actions, 2018). In Amsterdam and Utrecht, local governments together with housing corporations and civil society actors have created projects in which refugees live together with students (who likewise benefit from access to affordable, temporary housing).

Finally, communication between national governments and the local level may have to be improved, as becomes clear from the EUROCITIES (2016) report:

Communication with national authorities has proven difficult in some instances, with cities such as Barcelona, Bilbao and Nantes reporting that they were either informed late in the process or never at all about how many asylum seekers they should expect under the EU relocation scheme and how their reception would be funded. Many cities report that they have effectively acted instead of their competent national authority to provide reception to asylum seekers and migrants. (EUROCITIES, 2016, p. 7)

\subsection{Social Inclusion}

In terms of social inclusion, more broadly defined than labour market integration, there are interesting initiatives from cities. We found three examples through the subsidy platform for Urban Innovative Actions (2018):

The city of Bologna will look to foster the social, cultural and economic inclusion of migrants integrating different services in a new refurbished centre and allowing migrants to acquire new skills and build microenterprises for community services in the neighbourhood. Asylum seekers' entrepreneurial skills will be capitalised in the city of Utrecht combining community housing and learning activities. The city of Vienna will create a one-stop-shop for refugees that will bring together municipal services with grass roots initiatives through new forms of social cooperatives. (Urban Innovative Actions, 2018)

Also here the great autonomy of cities becomes clear, as well as their opportunities to work together with civil society and other local actors.

In the sphere of spatial and socio-economic integration, we can see just how much autonomy and creativity cities have to address challenges. Local governments have the advantage of being close to their population: the immigrants as well as employers and civil society. Case managers and coaches, as well as the practice of intake conversations, allow cities to get to know refugees and to match them properly to the labour market. Contacts with housing corporations and civil society make it possible to use housing for integration of refugees and other migrants as well as promoting overall social cohesion. However, national and supranational logics also frustrate such local policies. The allocation of human capital, which is determined by national governments and-indirectly-by the Dublin regulation often does not match local labour market needs. And national housing rules are often too strict to allow for flexible and emergency housing which is necessary if municipalities find themselves with the task of housing large groups at once.

What we have not found much trace of are big city interests in the cultural-religious domain. One might suspect two reasons for this. First of all, the present urgency lies with the practical reception and integration of recently arrived refugees and less so with social cohesion among the cities' population at large. The main purpose of the networks we have surveyed seems to be policy change for practical purposes, and changes to that end in the relationship between levels of governance. Secondly, earlier city networks did extensively address social cohesion and inter-cultural relations, e.g., the Cities for Local Integration Policies (CLIP) program (Penninx, 2015). Indeed, generally speaking we do know cities tend to consider this to be an important policy field (Alexander, 2003; Jørgensen, 2012).

\subsection{Municipal Foreign Policies}

Interestingly, we also came across policy domains which fifteen years ago were not identified by Alexander (2003), in all likelihood because their emergence is more recent.

We see that city networks may take up a role in formulating transnational (i.e., beyond the EU) policy. One instance of a foreign-oriented network of municipalities is VNG International. VNG is the Association of Netherlands Municipalities, which reaches out with the aim of strengthening democratic local government worldwide by offering expertise. Its network is thus less aimed at sharing, mutual learning between equal part- 
ners and common lobbying than the other networks we came across. The projects of VNG International are manifold, but here again the relevance of migration and refugee protection for the local level becomes very clear. One example of its projects in the migration field is a local government resilience programme for the Middle East and North Africa. The objective is to "strengthen resilience at local government level in order to improve living conditions of the local population and refugees in host communities and refugee settlements" (VNG International, 2018c). Another project is located in Jordan and provides municipal assistance to Al Zaatari refugee camp. The municipality of Amsterdam sent experts from their offices to develop an integrated (scenario) planning approach for the camp, to address service planning bottlenecks arising from the Syrian refugee influx, and to assist the local government to develop a development vision and plan for the region (VNG International, 2018b).

Also in Georgia, rights of migrants are protected, especially aiming to protect them from exploitation and trafficking, offering durable livelihood solutions for returning migrants, prevention of irregular migration and capacity building for NGOs working in migration management. VNG International also "assists in the fight against irregular migration" (VNG International, 2018a). In this instance, the VNG works in line with European and national policy goals: migration is linked to security issues such as trafficking and irregular migration (Huysmans, 2006).

CEMR also developed some notions resembling a foreign policy. For instance, this city network called for a more critical assessment in terms of international and European human rights and asylum law of the so-called "Turkey deal". It also explicitly mentions forms of transnational solidarity with mayors from across Europe and the Balkans, Turkey, and the Middle East, notably Lebanon and Jordan. For instance, it requests that the EU respects local and regional self-governance, for instance in relation to refugee reception in the region.

Cities do not only develop an external foreign policy, but also an intra-European vision. Cities call for solidarity and demand "increased efforts to better coordinate actions in dialogue between local, regional and national governments and to distribute refugees fairly and with solidarity across all regions and municipalities at the European level" (CEMR, 2016, p. 3). One important instrument for this is policy harmonisation, the need for which cities often emphasize.

\subsection{Policy Harmonisation and Policy Transfer}

Related to transnational policies, but a dimension in its own right, cities take it upon themselves to work on the harmonisation of policies. One of the important goals of the Urban Agenda for the EU is to do so and to make it more evidence-based (Urban Agenda for the EU, 2016, p. 14):

There is across Europe a great richness of experiences and expertise on integration. Sharing this experience in a systematic way can help enhancing the capacity of local authorities to develop successful integration policies in several areas. More structural exchanges of practices and experiences between different levels of governance can increase the efficiency and coordination in addressing integration challenges. (Urban Agenda for the EU, 2016, p. 25)

CEMR (2016) demands further development of the partnership mechanism and a co-decision spirit between EU, national, regional and local levels within existing institutional structures. It argues that there is a need for specific funding for the local level. CEMR welcomes the initiative to allocate extra money towards migration issues, but it wants it to be allocated to the local and regional levels. It also argues that the local level has to do more in terms of exchange, peer reviewing and sharing of best practices.

UCLG (2018) likewise calls for the promotion of peerto-peer learning. They work for instance on building a network of local and national stakeholders in the Mediterranean at city level aiming to reinforce knowledge and capacities of local politicians, officials and practitioners. Besides, they report organizing many mayoral forums and conferences aimed at sharing good practices.

To conclude with Barber (2013), cities are indeed well connected and formulate and practice "foreign policies". We see how cities formulate statements, as well as engage in actions, in solidarity with localities outside Europe, as well as demand solidarity among cities within Europe. VNG International dispatches experts beyond the EU's borders and EUROCITIES calls for solidarity with the EU's border towns. Such internal solidarity should be achieved by policy harmonisation, for which the different city networks have taken various initiatives, such as conferences and platforms. These activities invariably go hand in hand with demands for more and direct funds from higher levels of governance, such as the EU.

\subsection{Public Awareness and Legitimacy}

Besides demanding a larger role within the implementation and design of the CEAS, cities see a role for themselves in involving local civil society organizations and in managing awareness and consensus building amongst the local population. As Urban Innovative Actions writes:

Cities have shown to play an important role in promoting positive public perception of migrants and refugees and an understanding among the public of the need and obligation to grant them protection. In order to encourage a positive reception work is being done by local governments and NGOs to help people understand migrant and refugee experiences. (Urban Innovative Actions, 2018)

CEMR and EUROCITIES explicitly mention this dimension and argue that the EU should provide more financial support for cities to manage public opinion. 
EUROCITIES, in a letter to the European Commission and national leaders, states that European cities are committed to non-discrimination and equality, and that these see a role for themselves in countering xenophobic and nationalistic narratives:

There remains a nationalistic, isolationist and at times xenophobic undertone to some debates at national and European level. This does nothing to support the long term integration of refugees and asylum seekers. (EUROCITIES, 2015b)

One concrete way of doing this is through "neighbourhood information sessions" as described in a EUROCITIES (2016) report on the city of Utrecht:

Utrecht hosted five neighbourhood information sessions to address residents' concerns about the arrival of refugees, and in particular the establishment of two refugee centres in key locations in the city. These sessions involved a range of stakeholders, including the vice mayor responsible for refugees and asylum seekers, the police chief and a doctor working in asylum centres. Neighbourhood stakeholders were invited to discuss issues such as safety with the police, local policy with the vice mayor, and volunteer activities. The meetings helped to reassure residents and encourage a positive attitude towards refugees. (EUROCITIES, 2016, p. 9)

\section{Conclusion}

We have shown that city governments "feel" they are underestimated and even neglected as agents in national and European policymaking with regards to migration, both in general terms as well as for refugee integration. Many documents studied call for more involvement of cities by emphasizing that migration is a local issue. We found that cities seek a bigger role in the legal-political domain: demanding involvement in the content of membership (for instance, by lobbying for free movement of refugees within the EU), shaping citizenship practices (for instance, by giving undocumented immigrants access to services that go beyond the national legal framework), but also by demanding more involvement in policy making and implementation of a future refugee reallocation scheme within Europe. We see that within the legalpolitical domain the focus is on a reform of the CEAS: giving input for this reform, but also demanding influence in the policy making and implementation of a reformed CEAS. Thus, on top of being actors who close the policy gaps caused at the national level (which in turn cannot be seen as detached from the European level), cities identify larger roles for themselves and in their own right, organized horizontally as networks addressing refugee issues. To this end they each and jointly seek new and expand existing vertical relationships, bypassing the national level and tapping into European resources.
Secondly, cities develop innovative initiatives regarding spatial and socio-economic inclusion of recently arrived refugees, especially focusing on labour market integration. They bank on the advantage of being relatively close to both immigrants and local companies, and on working as mediators to match the demand and supply of human capital. Furthermore, cities put a lot of effort into 'seeing' and knowing refugees' skills and expertise in order to be able to match them to a job. Local companies are actively included and cooperate with municipalities. We have also seen how, in stark contrast, the allocation of refugees organized at the level of national governments appears to much less-or indeed not-match the local demands for labour.

Finally, we find that cities see immigrants more naturally as social capital as compared to the national level where the "immigrant as a threat" imagery is more readily invoked. Indeed, the overall message in the city networks' policy statements is one of inclusion and respect for human rights and thus an explicit willingness to act where national governments fail to deliver in both practical and moral terms.

\section{Acknowledgements}

We gladly mention that the writing of this article took place as part of the CEAS evaluation project, which has been made possible by a grant from the European Commission's Horizon2020 programme. We are also very grateful to the three anonymous reviewers for their critical yet constructive and detailed comments.

\section{Conflict of interests}

The authors have no conflicting interests to declare.

\section{References}

Alexander, M. (2003). Local policies toward migrants as an expression of Host-Stranger relations: A proposed typology. Journal of Ethnic and Migration Studies, 29(3), 411-430.

Barber, B. (2013). If mayors ruled the world: Dysfunctional nations, rising cities. New Haven, CT: Yale University Press.

Bauböck, R. (2003). Reinventing urban citizenship. Citizenship Studies, 7(2), 139-160.

Bauder, H. (2017). Sanctuary cities: Policies and Practices in International perspective. International Migration, 55(2), 174-187.

Caponio, T., \& Borkert, M. (Eds.). (2010). The local dimension of migration policymaking. Amsterdam: Amsterdam University Press.

Council of European Municipalities and Regions. (2015). Refugee crisis. For a common European asylum policy at all levels of government (CEMR Resolution). Brussels: Council of European Municipalities and Regions. Retrieved from www.ccre.org/img/uploads/ 
piecesjointe/filename/CEMR_resolution_refugees_ final_EN-0.pdf

Council of European Municipalities and Regions. (2016). Call for a common European asylum policy at all levels of government. Brussels: Council of European Municipalities and Regions. Retrieved from www.ccre. org/img/uploads/piecesjointe/filename/CEMR_Call_ for_a_real_common_european_asylum_policy_EN.pdf

Council of European Municipalities and Regions. (n.d.). Local \& regional Europe. Council of European Municipalities and Regions. Retrieved from www.ccre.org

Daamen, R., \& Doomernik, J. (2014). Local solutions for federal problems: Immigrant incorporation in Montgomery County, Maryland. Urban Geography, 35(4), 550-566.

De Mulder, J. (2017). De uitdagingen voor het migratieen integratiebeleid lopen van het Europese tot het lokale niveau [The challenges for migration and integration policy run from the European to the local level]. Praktijkgids Management Lokale Besturen, 2017(Juni), 150-263.

De Graauw, E., \& Vermeulen, F. (2016), Cities and the politics of immigrant integration: A comparison of Berlin, Amsterdam, New York City, and San Francisco. Journal of Ethnic and Migration Studies, 42(6), 989-1012.

Den Heijer, M., Rijpma, J. J., \& Spijkerboer, T. (2016). Coercion, prohibition, and great expectations. The continuing failure of the Common European Asylum System. Common Market Law Review, 53, 607-642.

Doomernik, J., \& Jandl, M. (Eds.). (2008). Modes of migration control and regulation in Europe. Amsterdam: Amsterdam University Press.

Doomernik, J., \& Glorius, B. (2016). Introduction to the special issue. Journal of Refugee Studies, 29(4), 429-439.

EUROCITIES. (n.d.). About us. Eurocities. Retrieved from www.eurocities.eu/eurocities/about_us

EUROCITIES. (2015a). Statement on asylum in cities. Eurocities. Retrieved from www.eurocities.eu/euro cities/documents/EUROCITIES-statement-on-asylum -in-cities-WSPO-9WFNGE

EUROCITIES. (2015b). Open letter from mayors to EU leaders. Eurocities. Retrieved from www.eurocities. eu/eurocities/documents/World-Refugee-Day-openletter-from-EUROCITIES-mayors-to-EU-leaders-WSPO -AB4GXE

EUROCITIES. (2016). Refugee reception and integration in cities. Eurocities. Retrieved from ec.europa.eu/ futurium/en/inclusion-migrants-and-refugees/euro cities-report-refugee-reception-and-integration-cities

Garcés-Mascarenas, B., \& Chauvin, S. (2016). Undocumented migrants: Between inclusion and exclusion. In V. Mamadouh \& A. van Wageningen (Eds.), Urban Europe: Fifty tales of the city (pp. 51-57). Amsterdam: Amsterdam University Press,

Glorius, B., \& Doomernik, J. (Eds.). (2016). Refugee migration and local demarcations: New insight into European localities. Journal of Refugee Studies, 29(4),
429-439.

Hollifield, J. F., Martin, P. L., \& Orrenius, P. M. (2014). The dilemmas of immigration control. In J. F. Hollifield, P. L. Martin, \& P. M. Orrenius (Eds.), Controlling immigration. A global perspective (pp. 3-34). Stanford, CA: Stanford University Press.

Huysmans, J. (2006). The politics of insecurity: Fear, migration and asylum in the EU. New York, NY: Routledge.

Isin, E. F. (2000). Introduction: democracy, citizenship and the city. In E. F. Isin (Ed.), Democracy, citizenship and the global city (pp. 1-21). Abingdon: Routledge.

Jørgensen, M. B. (2012). The diverging logics of integration policy making at national and city level. International Migration Review, 46(1), 244-278.

Kos, S., Maussen, M., \& Doomernik, J. (2016). Policies of exclusion and practices of inclusion: How municipal governments negotiate asylum policies in the Netherlands. Territory, Politics, Governance, 4(3), 354-374.

Kratz, B., \& Nowak, J. (2017). The new localism. How cities can thrive in the age of populism. Washington, DC: Brookings.

OECD. (2017). Who bears the cost of integrating refugees? Paris: OECD. Retrieved from www.oecd. org/els/mig/migration-policy-debates-13.pdf

Penninx, R. (2015). European cities in search of knowledge for their integration policies. In P. Scholten, $\mathrm{H}$. Entzinger, R. Penninx, \& S. Verbeek (Eds.), Integrating immigrants in Europe (pp. 99-117). Berlin: Springer.

Razenberg, I., \& De Gruijter, M. (2017). De rol van gemeenten bij arbeidsparticipatie van vluchtelingen [The role of municipalities in refugees' labour participation]. Utrecht: Kennisplatform Integratie en Samenleving.

Smith, A., \& Levoy, M. (2017). Cities of rights, ensuring health care for undocumented residents. Brussels: PICUM.

Spencer, S. (2018). Multi-level governance of an intractable policy problem: Migrants with irregular status in Europe. Journal of Ethnic and Migration Studies, 44(12), 2034-2052.

United Cities and Local Governments. (2018). Mediterranean city-to-city migration profiles and dialogue (C2C Project). United Cities and Local Governments. Retrieved from www.uclg.org/en/issues/migration

United Cities and Local Governments. (n.d.). United cities and local governments. UCLG. Retrieved from www.uclg.org

Urban Agenda for the EU. (2016). Pact of Amsterdam. Agreed at the informal meeting of EU ministers responsible for urban matters on 30 May 2016 in Amsterdam, the Netherlands. Europa. Retrieved from ec. europa.eu/regional_policy/sources/policy/themes/ urban-development/agenda/pact-of-amsterdam.pdf

Urban Agenda for the EU. (2017). Action plan partnership on inclusion of migrants and refugees. European Commission. Retrieved from ec.europa.eu/futurium /en/inclusion-migrants-and-refugees/final-action-plan 
-partnership-inclusion-migrants-and-refugees

Urban Agenda for the EU. (n.d.). Urban agenda for the EU. Europa. Retrieved from ec.europa.eu/futurium/ en/urban-agenda

Urban Innovative Actions. (2018). UIA cities. Urban Innovative Actions. Retrieved from www.uia-initiative. eu/en/uia-cities

Urban Innovative Actions. (n.d.). Urban innovative actions. UIA-Initiative. Retrieved from www.uiainitiative.eu/en

Varsanyi, M. (2006). Interrogating "urban citizenship" visà-vis undocumented migration. Citizenship Studies, 10(2), 229-249.

VNG International. (2018a). Georgia, promoting migration management in Georgia through research-based advocacy, awareness, networking and use of technologies. VNG International. Retrieved from www. vng-international.nl/blog/projects/georgia-promoting -migration-management-in-georgia-through-research -based-advocacy-awareness-networking-and-use-of- technologies

VNG International. (2018b). Jordan, municipal assistance to Al Zaa'tari refugee camp and local governments in Al Mafraq Governorate. VNG International. Retrieved from www.vng-international.nl/blog/projects/ jordan-municipal-assistance-to-al-zaa\%c2\%92tarirefugee-camp-and-local-governments-in-al-mafraqgovernorate

VNG International. (2018c). Building resilience in the Lebanon Beqaa' Valley. VNG International. Retrieved from www.vng-international.nl/home/ building-resilience-in-the-lebanon-beqaa-valley

VNG International. (n.d.). Welcome to VNG International. VNG International. Retrieved from www.vnginternational.nl

Zapata-Barrero, R., Caponio, T., \& Scholten, P. (2017). Theorizing the 'local turn' in a multi-level governance framework of analysis: A case study in immigrant policies. International Review of Administrative Sciences, 83(2), 241-246.

\section{About the Authors}

Jeroen Doomernik holds an MA in Social Anthropology and a PhD in Human Geography. He was a senior researcher at the Institute for Migration and Ethnic Studies (IMES) of the University of Amsterdam, mainly involving policy evaluations for governmental and international organizations. He also served as a policy advisor for the Dutch Ministry of the Interior. Presently, he is an assistant professor in political science. His research interests are refugee integration, irregular migration and human smuggling, and the future of the Common European Asylum System.

Djoeke Ardon is a Public Policy Researcher with a special interest in migration and integration issues. After finishing a research master at the University of Amsterdam, she worked with Jeroen Doomernik for the CEAS evaluation project, resulting in this article. Currently, she is working for the Netherlands Court of Audit as a researcher. 